\title{
Analisa Ketahanan dan Stabilitas Bank Syariah yang Melakukan Merger
}

\author{
Anita Dwi Utami ${ }^{1)}$, Citra Sukmadilaga ${ }^{2)}$, Lucky Nugroho ${ }^{3 *}$ \\ ${ }^{1 *}$ Magister Akuntansi, Universitas Padjadjaran, Jl. Japati No.4 Bandung, Jawa Barat 40133 \\ ${ }^{2)}$ Fakultas Ekonomi dan Bisnis, Universitas Padjadjaran Jl. Dipati Ukur No. 35 Bandung \\ Jawa Barat 40132 \\ ${ }^{3)}$ Fakultas Ekonomi dan Bisnis, Universitas Mercu Buana, Jalan Meruya Selatan No 31, \\ Jakarta Barat, Jakarta 11610 \\ E-mail penulis korespondensi: lucky.nugroho@mercubuana.ac.id
}

\begin{abstract}
ABSTRAK
Merger dari ketiga bank syariah yaitu Bank Syariah Mandiri (BSM), Bank BNI Syariah (BNIS), dan Bank BRI Syariah (BRIS) diharapkan dapat meningkatkan pangsa pasar perbankan syariah meningkat. Selain bertujuan meningkatkan daya saing, aksi korporasi merger tersebut diharapkan dapat menciptakan Bank Syariah yang masuk ke dalam 10 Top Global menurut kapitalisasi serta menyediakan produk dan layanan yang sesuai dengan prinsip-prinsip syariah. Tujuan dari penelitian ini adalah untuk menganalisa kualitas bank yang melakukan merger tersebut ditinjau dari aspek ketahanan dan stabilitas. Adapun unsur ketahanan direpresentasikan oleh Modal Inti yang direpresentasikan dengan Capital Adequacy Ratio (CAR) dan Non Performing Financing (NPF). Sedangkan stabilitas direpresentasikan dengan variabel Return on Aset (ROA), Financing to Deposit Ratio (FDR), dan Cost Efficiency Ratio (CER). Metode yang digunakan adalah statistik deskriptif dengan membandingkan aspek ketahanan dan stabilitas dari bank-bank yang melakukan merger tersebut dengan menggunakan bobot sesuai dengan ketentuan regulator. Hasil dari penelitian adalah BSM memiliki ketahanan dan stabilitas yang paling baik, diikuti oleh BNIS yang berada di peringkat 2 . Selanjunya BRIS menduduki tempat terakhir dari segi aspek ketahanan dan stabilitas dalam bank syariah yang melakukan merger. Implikasi manajerial adalah sebaiknya BSM sebagai bank yang memiliki kinerja yang paling baik dan memiliki pengalaman paling lama dapat dijadikan pengelola utama dari bank hasil merger tersebut. Selain itu teori dari penelitian ini adalah memberikan informasi kepada masyarakat dan juga bank hasil merger bahwa aksi korporasi tidak berhenti setelah merger tetapi konsolidasi internal yang menerapkan azas keadilan sesuai dengan kontribusi dan pengalaman masing-masing bank tersebut patut untuk dipertimbangkan. Originalitas dari penelitian ini adalah melakukan analisa ketahanan dan stabilitas terhadap bank-bank yang melakukan merger.
\end{abstract}

Kata kunci: Bank Syariah; Merger; Ketahanan; Stabilitas

\begin{abstract}
The merger of the three sharia banks, namely Bank Syariah Mandiri (BSM), Bank BNI Syariah (BNIS), and Bank BRI Syariah (BRIS), has occurred on February 1, 2021. The bank resulting from the merger is expected to increase market share so that the market share of Islamic banking ride. However, the purpose of this merger is not merely to increase competitiveness. Therefore, with the corporate action, the merger is expected to create Islamic banks included in the Top 10 Global by capitalization and provide products and services under sharia principles. This study aims to analyze the quality of the bank that did the merger in terms of resilience and stability. The element of resilience is represented by Core Capital, represented by the Capital Adequacy Ratio (CAR) and Non-Performing Financing $(N P F)$. At the same time, stability is represented by the variables Return on Assets (ROA), Financing to Deposit Ratio (FDR), and Cost Efficiency Ratio (CER). The
\end{abstract}


method used is descriptive statistics by comparing the aspects of resilience and stability of the banks conducting the merger using weights following the provisions of the regulator. The observation period in this study is from 2016 to 2020. The results of the study are that BSM has the best resilience and stability. Meanwhile, BNIS has resilience and stability ranked 2 after BSM. Furthermore, BRIS occupies the last place in aspects of resilience and stability in the merged sharia bank. The managerial implication is that BSM, as a bank with the best performance and the longest experience, can be the main manager of the merged bank (Bank Syariah Indonesia). In addition, the theory of this research is to provide information to the public and the merged bank that corporate actions do not stop after the merger. Still, internal consolidation that applies the principle of justice following the contribution and experience of each bank is worth considering. Therefore, the originality of this research is to analyze the resilience and stability of the merged banks.

Keyword: Islamic Bank; Mergers; Resilience; Stability.

\section{PENDAHULUAN}

Perbankan merupakan lokomotif perekonomian suatu negara yang dapat menggerakkan sektor riil karena sesuai dengan fungsinya yaitu memobilisasi dana di masyarakat (Muniarty et al., 2020; I. Setiawan, 2020). Selanjutnya, berdasarkan regulasi pemerintah, maka Indonesia memiliki 2 macam operasional perbankan yang terdiri dari bank konvensional dan bank syariah (Sukmadilaga \& Nugroho, 2017). Selain itu, merujuk pada UU Nomor 21 Tahun 2008 perihal Perbankan Syariah, maka Bank Syariah merupakan lembaga intermediari yang melaksanakan kegiatan usaha dengan prinsip syariah, atau prinsip hukum islam yang diatur pada fatwa Majelis Ulama Indonesia (MUI) seperti prinsip keadilan dan keseimbangan ('adl wa tawazun), kemaslahatan (maslahah), universalisme (alamiyah), serta tidak mengandung gharar, maysir, riba, zalim dan obyek yang haram (Aziz et al., 2021; Ihwanudin et al., 2020).

Pertumbuhan perbankan syariah di Indonesia sangat pesat. Hal ini dibuktikan pada akhir tahun 2020, bank syariah di Indonesia yang terdaftar di Otoritas Jasa Keuangan (OJK) sebanyak 14 bank umum syariah, 20 unit usaha syariah, dan 164 Bank Pembiayaan Rakyat Syariah (Yanti, 2020). Perkembangan perbankan syariah yang pesat harus disertai dengan kinerja yang bagus, baik dilihat dari aspek keuangan maupun non-keuangan. Kinerja perbankan syariah adalah capaian prestasi yang telah diraih selama kegiatan operasionalnya.

Pada 01 Februari 2021, tiga bank syariah milik BUMN yaitu Bank Syariah Mandiri (BSM), Bank BNI Syariah (BNIS), dan Bank BRI Syariah (BRIS) melakukan merger dengan tujuan menjadikan tonggak kebangkitan ekonomi dan keuangan syariah di Indonesia. Bank hasil penggabungan tersebut diharapkan dapat meningkatkan pangsa pasar sehingga pangsa pasar perbankan syariah naik menjadi 10\% yang semula di angka kisaran 6\% (Hidayat \& 
Antara, 2020). Namun, tujuan merger ini bukan semata-mata meningkatkan daya saing, dengan adanya merger dapat menciptakan Bank Syariah yang masuk ke dalam 10 Top Global menurut kapitalisasi serta menyediakan produk dan layanan masyarakat dengan mengedapankan etika sesuai dengan prinsip-prinsip syariah serta berkontribusi signifikan dalam meningkatkan kesejahteraan masyarakat dan juga internal pegawai bank syariah tersebut (Nugroho, Hidayah, Badawi, \& Mastur, 2020; Nugroho, Utami, Sukmadilaga, \& Fitrijanti, 2017). Diharapkan dengan dilakukannya aksi merger antar bank syariah, maka bank syariah hasil merger dapat berkompetisi dengan bank konvensional yang bertujuan meningkatkan kemashlahatan yang bagi masyarakat. Prinsip-prinsip syariah aksi korporasi merger ini harus sesuai dengan Al-Qur'an dan hadist karena prinsip syariah bersifat adil dan dapat menjaga keseimbangan dalam menjalakan hidup sesuai dengan ajaran agama. Sehingga Islam benar-benar menjadi umat yang unggul. Seperti firman Allah SWT dalam Q.S AliImran ayat 110 yang artinya: "Kamu adalah umat yang terbaik yang dilahirkan untuk manusia, menyuruh kepada yang ma'ruf, dan mencegah dari yang munkar, dan beriman kepada Allah.”

Selanjutnya, merujuk pada Laporan Bank Sentral per 30 September 2020 didapatkan data total aset bank bank-bank yang ada di Indonesia termasuk BSM, BNIS, dan BRIS sebelum melakukan merger yaitu sebagai berikut:

Tabel 1. Total Aset dan Pangsa Pasar Perbankan Indonesia, per 30 September 2020

\begin{tabular}{|c|c|c|c|}
\hline Nama Bank & $\begin{array}{l}\text { Total Aset (IDR } \\
\text { Triliun) }\end{array}$ & Peringkat & $\begin{array}{c}\text { Pangsa Pasar } \\
(\%)\end{array}$ \\
\hline Bank Rakyat Indonesia (BRI) & 1,448 & 1 & 16,0 \\
\hline Bank Mandiri & 1,407 & 2 & 15,5 \\
\hline Bank Central Asia (BCA) & 1,004 & 3 & 11,1 \\
\hline Bank Negara Indonesia (BNI) & 917 & 4 & 10,1 \\
\hline Bank Tabungan Negara (BTN) & 357 & 5 & 3,9 \\
\hline Bank CIMB Niaga & 282 & 6 & 3,1 \\
\hline Panin Bank & 217 & 7 & 2,4 \\
\hline OCBC NISP & 198 & 8 & 2,2 \\
\hline Bank Danamon & 197 & 9 & 2,2 \\
\hline $\begin{array}{l}\text { Bank Tabungan Pensiunan } \\
\text { Nasional (BTPN) }\end{array}$ & 187 & 10 & 2,1 \\
\hline Bank Mandiri Syariah (BSM) & 119 & 13 & 1,3 \\
\hline Bank BRI Syariah (BRIS) & 56 & +20 & 0,6 \\
\hline Bank BNI Syariah (BNIS) & 52 & +20 & 0,6 \\
\hline
\end{tabular}

Sumber: OJK (2020)

BSM memiliki total Aset sebesar IDR 119 Triliun dan berada pada peringkat 13 perbankan di Indonesia. Sedangkan BNIS dan BRIS memiliki total aset hanya di angka IDR 
56 Triliun dan IDR 52 triliun dan berada diperingkat lebih dari 20 dalam perbankan di Indonesia. Tentu perbandingan total aset BSM memiliki angka yang jauh signifikan lebih tinggi dibandingkan dengan BNIS dan BRIS. Berikut merupakan gambaran jika penggabungan bank syariah tersebut dilaksanakan:

Tabel 2. Perbandingan Aset dan Pangsa Pasar Bank Syariah Merger dengan Bank Lainnya di Indonesia Tahun 2021

\begin{tabular}{lccc}
\hline \multicolumn{1}{c}{ Nama Bank } & $\begin{array}{c}\text { Total Aset (IDR } \\
\text { Triliun) }\end{array}$ & Peringkat & $\begin{array}{c}\text { Pangsa Pasar } \\
(\boldsymbol{\%})\end{array}$ \\
\hline Bank Rakyat Indonesia (BRI) & 1,448 & 1 & 16,0 \\
Bank Mandiri & 1,407 & 2 & 15,5 \\
Bank Central Asia (BCA) & 1,004 & 3 & 11,1 \\
Bank Negara Indonesia (BNI) & 917 & 4 & 10,1 \\
Bank Tabungan Negara (BTN) & 357 & 5 & 3,9 \\
Bank CIMB Niaga & 282 & 6 & 3,1 \\
Bank Syariah Indonesia & $\mathbf{2 2 8}$ & $\mathbf{7}$ & $\mathbf{2 , 5}$ \\
Panin Bank & 217 & 8 & 2,4 \\
OCBC NISP & 198 & 9 & 2,2 \\
Bank Danamon & 197 & 10 & 2,2 \\
Bank Tabungan Pensiunan & 187 & 11 & 2,1 \\
Nasional (BTPN) & & & \\
\hline
\end{tabular}

Sumber: OJK (2020)

Pada tabel 2 merupakan ilustrasi jika tiga bank syariah melaksanakan penggabungan. Pada tabel tersebut, ketiga bank dilakukan merger maka hanya akan menghasilkan total aset sebesar IDR 228 triliun dan hanya naik menjadi peringkat 7 di perbankan Indonesia, secara signifikan berbeda jauh dengan bank konvensional. Peningkatan aset perbankan syariah tidak hanya dibutuhkan untuk meningkatkan pelayanan masyarakat, namun harus selaras dengan rencana pengembangan perbankan syariah. Sehingga bank hasil penggabungan dapat memperluas akses nasabah melalui jaringan outlet yang lebih besar dan layanan yang lebih baik.

Berdasarkan data yang dipublikasikan oleh Asian Banker, diperoleh bank syariah terkuat negara-negara Asean berdasarkan evaluasi neraca tahun 2020 yaitu sebagai berikut:

Tabel 3. Bank Syariah Terkuat Negara-Negara ASEAN Berdasarkan Evaluasi Neraca Tahun 2020

\begin{tabular}{|c|c|c|c|c|c|}
\hline Peringkat & Nama Bank & Negara & Peringkat & Nama Bank & Negara \\
\hline 1 & $\begin{array}{l}\text { Maybank } \\
\text { Islamic }\end{array}$ & Malaysia & 14 & $\begin{array}{l}\text { Bank NTB } \\
\text { Syariah }\end{array}$ & Indonesia \\
\hline 2 & $\begin{array}{l}\text { Bank Islam } \\
\text { Malaysia } \\
\text { HongLeong }\end{array}$ & Malaysia & 15 & $\begin{array}{l}\text { Alliance } \\
\text { Islamic Bank }\end{array}$ & Malaysia \\
\hline 3 & $\begin{array}{l}\text { Bank Islamic } \\
\text { Bank }\end{array}$ & Malaysia & 16 & RHB Islamic & Malaysia \\
\hline
\end{tabular}




\begin{tabular}{|c|c|c|c|c|c|}
\hline Peringkat & Nama Bank & Negara & Peringkat & Nama Bank & Negara \\
\hline 4 & Bank Rakyat & Malaysia & 17 & BIBD & $\begin{array}{c}\text { Brunei } \\
\text { Darussalam }\end{array}$ \\
\hline 5 & $\begin{array}{l}\text { Bank Syariah } \\
\text { Mandiri } \\
\text { (BSM) }\end{array}$ & Indonesia & 18 & $\begin{array}{l}\text { OCBC Al- } \\
\text { Amin }\end{array}$ & Malaysia \\
\hline 6 & $\begin{array}{l}\text { Public Islamic } \\
\text { Bank Berhad }\end{array}$ & Malaysia & 19 & $\begin{array}{l}\text { HSBC } \\
\text { Amanah }\end{array}$ & Malaysia \\
\hline 7 & $\begin{array}{l}\text { Bank Net } \\
\text { Syariah }\end{array}$ & Indonesia & 20 & $\begin{array}{l}\text { Bank } \\
\text { Muamalat }\end{array}$ & Malaysia \\
\hline 8 & BTPN Syariah & Indonesia & 21 & $\begin{array}{l}\text { Bank Victoria } \\
\text { Syariah }\end{array}$ & Indonesia \\
\hline 9 & $\begin{array}{l}\text { Bank Central } \\
\text { Asia Syariah }\end{array}$ & Indonesia & 22 & $\begin{array}{l}\text { Bank Aceh } \\
\text { Syariah }\end{array}$ & Indonesia \\
\hline 10 & $\begin{array}{l}\text { AmBank } \\
\text { Islamic } \\
\text { Bank BNI }\end{array}$ & Indonesia & 23 & $\begin{array}{l}\text { Bank Mega } \\
\text { Syariah } \\
\text { Bank BRI }\end{array}$ & Indonesia \\
\hline 11 & $\begin{array}{l}\text { Syariah } \\
\text { (BNIS) }\end{array}$ & Indonesia & 24 & $\begin{array}{l}\text { Syariah } \\
\text { (BRIS) }\end{array}$ & Indonesia \\
\hline 12 & CIMB Islamic & Malaysia & 25 & $\begin{array}{l}\text { Saadiq } \\
\text { Islamic Bank }\end{array}$ & Malaysia \\
\hline 13 & MBSB Bank & Malaysia & 26 & $\begin{array}{l}\text { Panin Dubai } \\
\text { Syariah Bank }\end{array}$ & Indonesia \\
\hline
\end{tabular}

Sumber: The Asian Banker (2021)

Dari data pada tabel 3 di atas, dapat dilihat bahwa bank terkuat berdasarkan evaluasi neraca tahun 2020 yaitu Maybank Islamic dari Malaysia. Sedangkan bank yang melakukan merger di Indonesia yaitu BSM, BNIS, dan BRIS masing-masing berada pada peringkat 5, 11, dan 24. BSM merupakan bank paling kuat dari ketiga bank yang melakukan merger berdasarkan evaluasi neraca tahun 2020. Demi menjaga stabilitas keuangan bank syariah, salah satu caranya adalah dengan memperkuat ketahanan bank dengan ukuran yang lebih besar. Besar kecilnya suatu bank syariah salah satunya diukur dengan modal yang dimilikinya. Merger yang dilakukan saat ini oleh BSM, BNIS, dan BRIS, menurut salah satu kepala OJK dari Surakarta yaitu Eko Yunianto, mengharapkan dengan adanya merger ini menjadikan penambahan modal sehingga menjadi Bank Syariah pertama BUKU IV (Wella \& Asriyanto, 2020). Selain itu, perbankan syariah dihadapkan dari berbagai risiko, salah satunya adalah kegiatan utama bank yaitu penyaluran dana. Betapa pentingnya bank menjaga penyaluran dana dan permodalannya agar mengetahui kondisi kesehatan bank syariah sehingga dapat menentukan kondisi perbankan syariah dimasa yang akan datang apakah mampu bertahan atau mengalami kebangkrutan supaya stabilitas perbankan syariah hingga sistem keuangan negara terjamin (Nugroho \& Bararah, 2018; Vania, Nugraha, \& Nugroho, 2018). 
Sementara itu, selain kondisi kesehatan bank syariah dapat mempengaruhi ketahanan perbankan syariah, hal tersebut juga mempengaruhi stabilitas perbankan syariah (Nugroho \& Anisa, 2018; Nugroho, Mastur, Harnovinsah, \& Aryanti, 2020). Kinerja bank syariah merupakan aspek yang menentukan stabilitas di perbankan syariah sehingga dapat menjaga kestabilan sistem keuangan. Kinerja bank syariah dapat dilihat dari aspek profitabilitas, likuiditas, dan efisiensi. BSM merupakan Bank Syariah BUMN yang paling besar di Indonesia. BNIS dan BRIS berada diperingkat 2 dan 3. Sehingga tidak ada salahnya jika pemerintah melaksanakan rencana merger tersebut menurut Komite Nasional Keuangan Syariah agar tercipta satu Bank Syariah BUMN yang mumpuni dan memiliki jangkauan yang luas. Berdasarkan fenomena di atas, maka rumusan masalah dalam penelitian ini adalah (i) Bagaimana aspek ketahanan dan aspek stabilitas BSM sebelum merger?, (ii) Bagaimana aspek ketahanan dan aspek stabilitas BNIS sebelum merger?, (iii) Bagaimana aspek ketahanan dan aspek stabilitas BRIS sebelum merger?, (iv) Bagaimana komparisi aspek ketahanan dan aspek stabilitas antara BSM, BNIS dan BRIS sebelum merger?. Merujuk dari rumusan masalah tersebut, maka tujuan dari penelitian ini adalah untuk menganalisa ketahanan dan stabilitas bank syariah yang melakukan merger. Adapun implikasi dari penelitian ini adalah untuk memberikan khasanah ilmu pengetahuan terkait bank syariah pada umumnya dan kondisi ketahanan dari bank-bank syariah yang melakukan merger agar terdapat kebijakan-kebijakan dan pertimbangan yang tepat dalam mengelola dan mengimplementasikan operasional bank hasil merger berdasarkan prinsip keadilan dan berkesinambungan.

Selanjutnya, menurut Arafah \& Nugroho (2016) dan Sabariah \& Nik Ab Halim (2020) konsep dari keberadaan bank syariah adalah memberikan kemaslahatan bagi seluruh umat sehingga dalam mengelola bank syariah harus menerapkan prinsip-prinsip syariah (maqasid syariah) yang mencakup (i) Menjaga agama, (ii) Menjaga jiwa, (iii) Menjaga akal, (iv) Menjaga keturunan, (v) Menjaga harta, (vi) Menjaga lingkungan. Oleh karenanya harapan atau ekspektasi dari aktivitas korporasi merger ini seharusnya tidak semata-mata terdapatnya bank syariah berskala besar akan tetapi mampu berkontribusi lebih besar terhadap aspek sosial dan aspek spiritual termasuk meningkatkan kemaslahatan yaitu terwujudnya kesejahteraan bagi masyarakat dan juga menjaga keberlangsungan bagi seluruh makhluk hidup (Matoenji et al., 2021). Menurut penelitian terdahulu yang dilakukan oleh Mersland \& Strøm (2008), semakin besar skala perusahaan maka semakin berkurang perusahaan tersebut memiliki kepedulian terhadap aspek sosial. Dengan demikian diperlukan kolaborasi dari seluruh stakeholder untuk melakukan monitoring eksternal dan keterbukaan 
terhadap masukan serta kritik dari manajemen bank syariah hasil merger agar keberadaan bank syariah di Indonesia dapat sesuai khittah-nya yaitu berasal dari masyarakat (society driven). Selain itu keberadaan dari bank syariah juga dapat berkontribusi positif terhadap implementasi nilai-nilai keadilan dan juga tercapainya kesejahteraan bagi seluruh stakeholder dan masyarakat (Nugroho \& Husnadi, 2014).

Strategi perusahaan untuk mengembangkan atau memperluas (ekspansi) usaha dapat melalui dua cara, yaitu internal dan eksternal. Ekspansi internal adalah pengembangan perusahaan yang dilakukan tanpa melibatkan organisasi di luar perusahaan. Sedangkan ekspansi eksternal adalah pengembangan perusahaan yang dilakukan dengan melibatkan organisasi diluar perusahaan. Ekspansi eksternal biasa disebut dengan penggabungan badan usaha (Boia, 2015). Ekspansi eksternal dapat dilakukan dengan dua cara, satu diantaranya adalah dengan melakukan merger (Esterlina, 2017). Oleh karenanya, salah satu usaha bank syariah untuk mengembangkan usahanya dan meningkatkan pangsa pasarnya, maka dilakukan merger (Nugroho, Utami, Sukmadilaga, et al., 2017).

\section{METODE PENELITIAN}

Penelitian ini menggunakan analisa statistik deskriptif. Data penelitian ini merupakan data sekunder publikasi laporan keuangan tahunan Bank Syariah Mandiri, Bank BNI Syariah, dan Bank BRI Syariah periode 2016-2020. Data penelitian diambil dari Laporan Tahunan Bank Umum Syariah yang dipublikasikan di Indonesia Stock Exchange (IDX), serta website masing-masing bank syariah tersebut. Periode data dipilih sebagai pertimbangan bahwa dalam 5 tahun terakhir bank yang melakukan merger menjadi Bank Syariah Indonesia harus mempunyai kesehatan bank yang baik dilihat dari aspek ketahanan dan stabilitas untuk melakukan merger sehingga jika bank-bank tersebut melakukan merger dengan keadaan masing-masing bank memiliki tingkat kesehatan yang baik maka menciptakan penggabungan bank yang lebih baik lagi. Adapun kerangka penelitian pada artikel ini adalah dapat diliat pada gambar 1 .

Merujuk pada gambar 1 kerangka penelitian, maka operasional untuk mengukur bobot variabel-variabel pada penelitian ini meliputi: (i) variabel modal inti; (ii) variabel capital adequacy ratio (CAR); (iii) variabel non performing financing (NPF); (iv) variabel return on assets (ROA); (v) variabel financing to deposit ratio (FDR); (vi) variabel biaya operasional terhadap pendapatan operasional. 


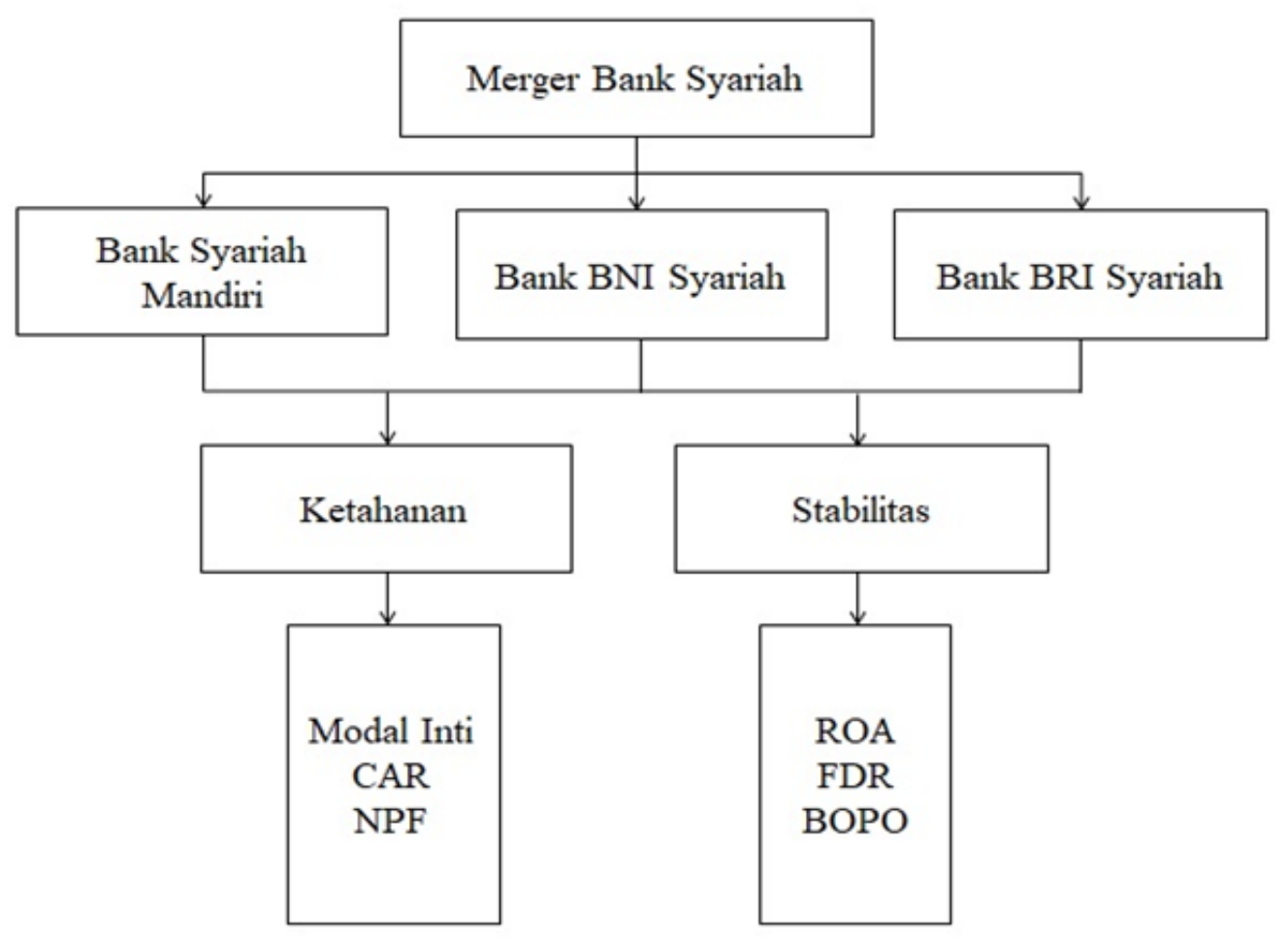

Gambar 1. Kerangka Penelitian

Sumber: Penulis

\section{Modal Inti}

Sumber utama dana bank syariah selain bersumber dari dana pihak ketiga (DPK) tetapi juga berasal dari modal inti dan kuasi ekuitas. Pengertian dari modal inti setoran modal yang disetor oleh para investor bank maupun pemilik dari bank. Lebih lanjut, modal dapat bersumber dari macam-macam yang terdiri dari modal yang disetor oleh pemegang saham, cadangan maupun laba ditahan. Selain itu definisi dari kuasi ekuitas adalah dana-dana yang terdapat pada rekening-rekening bagi hasil (mudharabah). Fungsi dari modal inti adalah sebagai pelindung dari bank dari kegagalan atau kerugian dan menjaga kepentingan para pemilik rekening titipan (wadiah) atau pinjaman (qard), terutama atas aktiva yang didanai oleh modal sendiri dan dana-dana wadiah atau qard (Miftakhul Jannah \& Nugroho, 2019; Nugroho, 2020). Dana-dana rekening bagi hasil (mudharabah) sebenarnya juga dapat dikategorikan sebagai modal, inilah yang biasanya disebut dengan kuasi ekuitas. Namun demikian, kuasi ekuitas hanya dapat menanggung risiko atas aktiva yang dibiayai oleh dana dari rekening bagi hasil itu sendiri (Ilyas, 2017). Adapun merujuk pada peraturan OJK Nomor 6/POJK.03/2016 tentang Kegiatan Usaha dan Jaringan Kantor membagi bank berdasarkan modal inti bank dan bobotnya dibagi pada tabel 4. 
Tabel 4. Bank Syariah Terkuat Negara-Negara ASEAN Berdasarkan Evaluasi Neraca Tahun 2020

\begin{tabular}{|c|c|c|}
\hline Kategori Bank & Kriteria & Bobot \\
\hline $\begin{array}{l}\text { Bank Umum Kegiatan Usaha } \\
\text { (BUKU) IV }\end{array}$ & $\begin{array}{l}\text { Bank dengan modal inti di atas Rp. } \\
30 \text { Triliun }\end{array}$ & 4 \\
\hline $\begin{array}{l}\text { Bank Umum Kegiatan Usaha } \\
\text { (BUKU) III }\end{array}$ & $\begin{array}{l}\text { Bank dengan modal inti di antara } \\
\text { Rp } 5 \text { - } 30 \text { Triliun }\end{array}$ & 3 \\
\hline $\begin{array}{l}\text { Bank Umum Kegiatan Usaha } \\
\text { (BUKU) II }\end{array}$ & $\begin{array}{l}\text { Bank dengan modal inti di antara } \\
\text { Rp. } 1 \text { - } 5 \text { Triliun }\end{array}$ & 2 \\
\hline $\begin{array}{l}\text { Bank Umum Kegiatan Usaha } \\
\text { (BUKU) I }\end{array}$ & $\begin{array}{l}\text { Bank dengan modal inti di bawah } \\
\text { Rp. } 1 \text { Triliun }\end{array}$ & 1 \\
\hline
\end{tabular}

Sumber: Otoritas Jasa Keuangan/OJK (2016)

\section{Capital Adequacy Ratio (CAR)}

Capital adequacy ratio (CAR) adalah rasio kinerja bank untuk mengukur kecukupan modal yang dimiliki bank untuk menunjang aset yang mengandung risiko. Surat edaran No 6/10/PBI/2004 tentang Sistem Penilaian Tingkat Kesehatan Bank Umum. Ketentuan yang salah satu diantaranya adalah mengatur tentang permodalan Bank minimum sebesar $8 \%$. Dengan demikian, salah satu cara untuk mengukur kecukupan modal suatu bank dapat menggunakan rasio CAR (Nugroho, Utami, Doktorlina, \& Husnadi, 2017; Soekapdjo, Tribudhi, \& Nugroho, 2019). Semakin tinggi CAR yang dimiliki oleh bank, maka akan semakin baik pula bank tersebut memiliki ketahanan untuk mengcover bank tersebut dari risiko yang akan terjadi. Oleh karenanya, indikator ketahanan suatu bank syariah salah satunya dapat ditentukan dengan modal yang dimilikinya atau dapat direpresentasikan dengan indikator CAR. Kriteria penetapan tingkat rasio CAR menurut Surat Edaran Bank Indonesia No. 9/24/DPbs/2007 berikut bobotnya terdapat pada tabel 5 di bawah ini:

Tabel 5. Kriteria Penetapan Tingkat Rasio CAR

\begin{tabular}{llc}
\hline \multicolumn{1}{c}{ Keterangan } & \multicolumn{1}{c}{ Kriteria } & Bobot \\
\hline Sangat Sehat & $\mathrm{CAR} \geq 12 \%$ & 5 \\
Sehat & $9 \% \leq \mathrm{CAR}<12 \%$ & 4 \\
Cukup Sehat & $8 \% \leq \mathrm{CAR}<9 \%$ & 3 \\
Kurang Sehat & $6 \% \leq \mathrm{CAR}<8 \%$ & 2 \\
Tidak Sehat & $\mathrm{CAR} \leq 6 \%$ & 1 \\
\hline
\end{tabular}

Sumber: Bank Indonesia (2007)

\section{Non Performing Financing (NPF)}

Definisi non performing loan atau financing (NPL/NPF) adalah kredit atau pembiayaan yang memiliki kolektibilitas kurang lancar (kolektibilitas 3), diragukan (kolektibilitas 4), atau macet (kolektibilitas 5) dimana rasio pembiayaan bermasalah neto 
(Non Performing Loan/NPL net) atau rasio pembiayaan bermasalah (NPF) secara neto tidak diperkenankan lebih dari 5\% (lima persen) dari total kredit atau total pembiayaan (Otoritas Jasa Keuangan/OJK, 2017). Non performing financing (NPF) merupakan tolak ukur suatu bank syariah dalam mengelola kemampuan manajemen bank dalam mengelola pembiayaan bermasalah. Semakin besar NPF semakin besar cadangan yang harus disediakan dan semakin besar pula opportunity cost yang harus ditanggung yang akhirnya dapat mengakibat kerugian pada bank (Effendi \& RS, 2020). Semakin tinggi NPF maka semakin banyak modal yang harus disediakan, karena semakin banyak pembiayaan macet akan mengurangi jumlah modal yang tersedia karena bank harus membentuk biaya cadangan kerugian penurunan nilai yang akan berdampak terhadap penurunan pendapatan bank (Hien \& Tuan, 2014; Sholikhah, 2019). Dengan demikian, rasio NPF dapat digunakan untuk mengukur pengelolaan kemampuan manajemen dalam mengelola pembiayaan bermasalah. Jika manajemen dapat mengelola pembiayaan bermasalah, maka perbankan dapat menjaga penyaluran dana dan permodalannya sehingga kondisi kesehatan bank syariah dapat diprediksi pada masa yang akan datang apakah mampu bertahan atau mengalami kebangkrutan (Nugroho, Villaroel, \& Utami, 2018; Widyatini, 2017). Kriteria penetapan tingkat rasio NPF menurut Surat Edaran Bank Indonesia No. 9/24/DPbs/2007 dan bobot penilaiannya terdapat pada tabel 6 berikut ini:

Tabel 6. Kriteria Penetapan Tingkat Rasio NPF

\begin{tabular}{llc}
\multicolumn{1}{c}{ Keterangan } & \multicolumn{1}{c}{ Kriteria } & Bobot \\
\hline Sangat Sehat & $0 \%<\mathrm{NPF}<2 \%$ & 5 \\
Sehat & $2 \% \leq \mathrm{NPF}>5 \%$ & 4 \\
Cukup Sehat & $5 \% \leq \mathrm{NPF}>8 \%$ & 3 \\
Kurang Sehat & $8 \%<\mathrm{NPF} \geq 12 \%$ & 2 \\
Tidak Sehat & $\mathrm{NPF}>12 \%$ & 1 \\
\hline
\end{tabular}

S u mber: Bank Indonesia (2007)

\section{Return on Assets (ROA)}

Return on assets (ROA) merupakan indikator yang mengungkapkan seberapa besar perusahaan mendapatkan keuntungan terhadap total aset. Oleh karenanya, indikator rasio ini memberikan informasi kepada manajer, investor, dan pihak eksternal lainnya untuk mengetahui seberapa efisien perusahaan mempergunakan asetnya untuk mendapatkan keuntungan (Hidayah, Nugroho, Prihanto, \& Prihantini, 2021; Nugroho, Aryani, \& Mastur, Akhmad Amien, 2019). Selain itu ROA adalah rasio yang digunakan untuk mengukur kemampuan bank syariah dalam memperoleh laba dan tingkat efisiensi usaha bank dimana semakin besar nilai rasio ROA menunjukkan tingkat rentabilitas bank semakin baik atau semakin sehat (Muin, 2017; A. Setiawan, 2017). Selain itu ROA juga merupakan rasio 
profitabilitas yang befungsi mengukur kinerja bank syariah dari aspek stabilitas. Jika rasio ini baik, maka perbankan dapat menjaga kestabilan sistem keuangannya sehingga bank dapat dikatakan sehat dalam melakukan kegiatan operasionalnya. Adapun kriteria penetapan tingkat ROA menurut Surat Edaran Bank Indonesia No. 9/24/DPbs/2007 dan juga bobot pengukurannya pada penelitian ini terdapat pada tabel 7 di bawah ini:

Tabel 7. Kriteria Penetapan Tingkat Rasio ROA

\begin{tabular}{llc}
\hline \multicolumn{1}{c}{ Keterangan } & \multicolumn{1}{c}{ Kriteria } & Bobot \\
\hline Sangat Sehat & $\mathrm{ROA}>1,5 \%$ & 5 \\
Sehat & $1,25 \%<\mathrm{ROA} \leq 1,5 \%$ & 4 \\
Cukup Sehat & $0,5 \%<\mathrm{ROA} \leq 1,25 \%$ & 3 \\
Kurang Sehat & $0 \%<\mathrm{ROA} \leq 0,5 \%$ & 2 \\
Tidak Sehat & $\mathrm{ROA} \leq 0 \%$ & 1 \\
\hline
\end{tabular}

S u m ber: Bank Indonesia (2007)

\section{Financing to Deposit Ratio (FDR)}

Financing to Deposit Ratio (FDR) merupakan rasio yang digunakan untuk mengukur suatu bank untuk memenuhi kewajibannya yang harus segera dipenuhi. Kewajiban ini adalah kewajiban yang harus dipenuhi pada saat adanya kewajiban kliring, dimana pada saat pemenuhannya dilarang dari aset lancar yang dimiliki oleh perusahaan. Selain itu bank syariah mendapatkan pendapatan melalui pembiayaan yang disalurkan. Jika rasio FDR terlalu tinggi bahkan di atas 100\%, maka dapat diartikan bahwa bank tidak memiliki likuiditas yang memadai untuk menutup kewajibannya kepada nasabah dan terlalu ekspansif. Namun, jika rasio FDR bank terlalu rendah maka dapat dikatakan bahwa bank syariah tersebut mempunyai likuiditas yang memadai untuk menutup kewajibannya kepada nasabah. Namun apabila FDR terlalu rendah bahkan apabila mencapai 50\%, maka bank syariah tersebut tidak mampu menyalurkan dananya dengan baik. Oleh karenanya FDR harus dapat dikendalikan dengan baik dan juga merupakan rasio likuiditas yaitu salah satu rasio yang mengukur kinerja bank syariah dari aspek stabilitas. Jika rasio ini baik, maka perbankan dapat menjaga kestabilan sistem keuangannya sehingga bank dapat dikatakan sehat dalam melakukan kegiatan operasionalnya. Berikut di bawah ini (tabel 8) merupakan kriteria FDR menurut Surat Edaran Bank Indonesia No. 9/24/DPbs/2007 dan bobot pengukuran pada penelitian ini: 
Tabel 8. Kriteria Penetapan Tingkat Rasio FDR

\begin{tabular}{llc}
\hline \multicolumn{1}{c}{ Keterangan } & \multicolumn{1}{c}{ Kriteria } & Bobot \\
\hline Sangat Sehat & $50 \%<$ FDR $\leq 75 \%$ & 5 \\
Sehat & $75 \%<$ FDR $\leq 85 \%$ & 4 \\
Cukup Sehat & $85 \%<$ FDR $\leq 100 \%$ & 3 \\
Kurang Sehat & $100 \%<$ FDR $\leq 110 \%$ & 2 \\
Tidak Sehat & FDR $>110 \%$ & 1 \\
\hline
\end{tabular}

S u m ber: Bank Indonesia (2007)

\section{Biaya Operasional terhadap Pendapatan Operasional (BOPO)}

Rasio Beban Operasional terhadap Pendapatan Operasional (BOPO) adalah rasio yang berfungsi mengukur seberapa efisien operasional perbankan syariah tersebut beroperasi. Rasio ini diukur oleh beban operasional dan pendapatan operasional. Rasio ini dapat digunakan oleh bank untuk mengendalikan biaya operasional terhadap pendapatan operasional. BOPO juga dapat digunakan untuk mengukur kemampuan manajemen bank dalam mengalokasikan sumber daya yang dimilikinya secara efektif (Pinasti \& Mustikawati, 2018; Syakhrun, Anwar, \& Amin, 2019). Biaya operasional yang lebih kecil dari pendapatan operasional menunjukkan semakin efektif pengalokasian sumber daya bank syariah tersebut (Nugroho et al., 2019). BOPO merupakan rasio efisiensi yang mengukur kinerja bank syariah dari aspek stabilitas. Jika rasio ini baik, maka perbankan dapat menjaga kestabilan sistem keuangannya sehingga bank dapat dikatakan sehat dalam melakukan kegiatan operasionalnya. Kriteria penetapan tingkat rasio biaya operasional terhadap pendapatan operasional (BOPO) menurut Surat Edaran Bank Indonesia No. 9/24/DPbs/2007 dan pengukuran bobot pada penelitian ini terdapat pada tabel 9 adalah sebagai berikut:

Tabel 9. Kriteria Penetapan Tingkat Rasio BOPO

\begin{tabular}{llc}
\hline \multicolumn{1}{c}{ Keterangan } & \multicolumn{1}{c}{ Kriteria } & Bobot \\
\hline Sangat Sehat & $\mathrm{BOPO} \leq 94 \%$ & 5 \\
Sehat & $94 \%<\mathrm{BOPO} \leq 95 \%$ & 4 \\
Cukup Sehat & $95 \%<\mathrm{BOPO} \leq 96 \%$ & 3 \\
Kurang Sehat & $96 \%<\mathrm{BOPO} \leq 97 \%$ & 2 \\
Tidak Sehat & $\mathrm{BOPO}>97 \%$ & 1
\end{tabular}

S u mber: Bank Indonesia (2007) 


\section{HASIL DAN PEMBAHASAN}

\section{Aspek Ketahanan dan Stabilitas Bank Syariah Mandiri (BSM)}

Hasil dari pengolahan data sekunder yang diperoleh, maka dapat diketahui aspek ketahanan dan stabilitas dari BSM pada periode 2016-2020 adalah sebagai berikut:

Tabel 10. Analisa Rasio Keuangan Bank Syariah Mandiri (BSM) Berdasarkan Aspek Ketahanan dan Stabilitas Periode 2016-2020

\begin{tabular}{|c|c|c|c|c|c|c|}
\hline \multirow{2}{*}{ Indikator } & \multicolumn{5}{|c|}{ Tahun } & \multirow{2}{*}{$\begin{array}{c}\text { Rata-rata } \\
\text { tingkat } \\
\text { kesehatan }\end{array}$} \\
\hline & 2016 & 2017 & 2018 & 2019 & 2020 & \\
\hline $\begin{array}{l}\text { Modal Inti (Jutaan } \\
\text { Rupiah) }\end{array}$ & 6.109 .151 & 6.943 .575 & 7.648 .915 & 8.705 .292 & 10.052 .432 & \\
\hline bobot & 3 & 3 & 3 & 3 & 3 & 3 \\
\hline \multicolumn{7}{|l|}{ Rasio } \\
\hline CAR $(\%)$ & 14,01 & 15,89 & 16,26 & 16,15 & 16,88 & \\
\hline bobot & 5 & 5 & 5 & 5 & 5 & 5 \\
\hline NPF $(\%)$ & 4,92 & 4,53 & 3,28 & 2,44 & 2,51 & \\
\hline bobot & 4 & 4 & 4 & 4 & 4 & 4 \\
\hline ROA $(\%)$ & 0,59 & 0,59 & 0,88 & 1,69 & 1,65 & \\
\hline bobot & 3 & 3 & 3 & 5 & 5 & 4 \\
\hline $\operatorname{FDR}(\%)$ & 76,83 & 75,43 & 74,89 & 75,54 & 73,98 & \\
\hline bobot & 4 & 4 & 5 & 4 & 5 & 4 \\
\hline BOPO (\%) & 94,12 & 94,44 & 90,68 & 82,89 & 81,81 & \\
\hline bobot & 4 & 4 & 5 & 5 & 5 & 5 \\
\hline \multicolumn{6}{|c|}{ TOTAL BOBOT } & 4,2 \\
\hline
\end{tabular}

Sumber: Data yang telah diolah oleh Penulis

Berdasarkan tabel 10 di atas, maka aspek ketahanan BSM ditinjau dari indikator modal inti bank menunjukkan bahwa BSM termasuk dalam kriteria bank BUKU III, sebab modal inti selama tahun penelitian berada diantara Rp5 triliun s.d Rp30 triliun selama periode 2016-2020. Modal inti digunakan sebagai penyangga serta penyelamat bank dari risiko kegagalan. Oleh karenanya BSM sebagai bank BUKU III memiliki permodalan yang kuat dan terus meningkat dari tahun ke tahun (2016-2020) sehingga BSM memiliki kemampuan memitigasi dan mengantisipasi risiko serta mampu bertahan dalam kondisi kritis sekalipun. Jika dilihat dari peraturan OJK Nomor 12/POJK.03/2020 tentang Konsolidasi Bank Umum, bank wajib memenuhi modal inti minimum paling lambat 31 Desember 2022 sebesar Rp3.000.000.000.000 (tiga triliun rupiah) (Otoritas Jasa Keuangan/OJK, 2020). Tetapi, pada BSM jika ditinjau dari modal inti yang dimiliki pada periode tahun 2016-2020 menunjukkan sebesar Rp10 triliun sehingga dapat dikatakan modal BSM telah tiga kali lipat lebih besar dari minimal modal yang telah disyaratkan. Kemudian kondisi ketahanan BSM dianalisa dari indikator rasio CAR menunjukkan rata-rata tingkat kesehatan BSM pada tahun 2016-2020 menunjukkan sangat sehat. Dimana rasio CAR tahun 2016-2020 menunjukkan di atas $12 \%$, artinya BSM selama tahun 2016-2020 memiliki kecukupan modal yang memadai 
dalam menunjang bisnisnya sehingga kegiatan operasional yang dilakukan oleh BSM dapat berjalan sesuai optimal serta bank dapat tetap melakukan ekspansi bisnisnya. Lebih lanjut, merujuk pada penelitian dari (Marlyna \& Wirando, 2018), menunjukkan bahwa jika bank syariah memiliki CAR yang sehat maka dapat dikatakan bank syariah tersebut memiliki kemampuan yang baik dalam memitigasi dari risiko kerugian yang akan terjadi di masa yang akan datang. Sedangkan, aspek ketahanan ditinjau dari rasio rasio pembiayaan bermasalah (NPF) menunjukkan rata-rata tingkat kesehatan BSM pada tahun 2016-2020 menunjukkan sehat, karena nilai NPF BSM berada pada range 2\% $\leq \mathrm{NPF}>5 \%$ sehingga sesuai kriteria dalam surat edaran Bank Indonesia No.9/24/DPbs/2007 pada kisaran tersebut perbankan dapat dikatakan sehat. NPF merupakan tolak ukur untuk bank syariah melakukan penilaian terhadap pembiayaan bermasalah. Jadi, jika NPF diatas range 5\% maka perlu diadakan pengawasan dan tindak lanjut dari pihak bank untuk melakukan penagihan secara intensif. Hal tersebut sejalan dengan penelitian Afoukane et al. (2021) dan Nugroho \& Malik (2020), menunjukkan bahwa jika semakin besar pembiayaan bermasalah (NPF), maka cadangan NPF yang harus disediakan akan semakin besar pula opportunity cost yang harus ditanggung oleh bank syariah sehingga mengurangi pendapatan dari bank syariah. Dengan demikian, berdasarkan berdasarkan aspek-aspek ketahanan, maka BSM dapat menjaga penyaluran dana dan permodalannya sehingga kondisi bank di masa yang akan datang dianggap mampu bertahan dalam situasi krisis sekalipun.

Selanjutnya, merujuk kesehatan bank ditinjau berdasarkan aspek stabilitas dengan menggunakan rasio profitabilitas yaitu ROA memperlihatkan bahwa rata-rata tingkat kesehatan BSM pada tahun 2016-2020 menunjukkan cukup sehat, karena pada tahun 20162018 rasio ROA BSM menunjukkan di bawah angka 1\% dan cenderung meningkat secara signifikan di tahun 2019 dan 2020 menjadi di atas 1,5\%. Oleh karena itu, profitabilitas BSM ditinjau dari seberapa besar perusahaan mendapatkan keuntungan terhadap total aset memiliki tren yang selalu membaik dari tahun ke tahun sehingga memberikan peningkatan kepercayaan kepada seluruh stakeholder. Hal tersebut sejalan dengan hasil penelitian (Wilara \& Basuki, 2016), menunjukkan bahwa dalam jangka pendek maupun jangka panjang ROA mengalami kenaikan maka dapat mengindikasi keuntungan yang diperoleh bank syariah, sehingga dapat meningkatkan kemampuan bank syariah dalam meningkatkan modal. Selanjutnya jika kondisi kesehatan BSM dianalisa dari aspek stabilitas dengan menggunakan rasio likuiditas yaitu FDR memperlihatkan bahwa rata-rata tingkat kesehatan BSM pada tahun 2016-2020 menunjukkan sehat sebab selama tahun penelitian nilai FDR di bawah 85\% sehingga dapat dikatakan bahwa BSM memiliki likuiditas yang memadai untuk menutup 
kewajibannya kepada nasabah dan penyaluran pembiayaan dilakukan dengan berhati-hati. Oleh karenanya stabilitas keuangan BSM dapat dijaga dengan baik. Menurut penelitian (Wilara \& Basuki, 2016), menunjukkan bahwa FDR akan membawa dampak jika dilihat dari aspek jangka pendek maupun jangka panjang, sehingga apabila FDR mengalami kenaikan maka kemampuan bank syariah dalam mengelola dana akan menurunkan CAR sehingga dapat dikatakan tidak sehat. Tetapi, selama periode penelitian yang dilakukan oleh peneliti, FDR BSM mengalami penurunan sehingga berbanding terbalik dari hasil penelitian (Wilara \& Basuki, 2016), sehingga dapat dikatakan bahwa BSM mampu mengelola dana dan menaikkan CAR. Sedangkan aspek stabilitas jika dianalisa berdasarkan rasio efisiensi yaitu BOPO menunjukkan bahwa rata-rata tingkat kesehatan BSM menunjukkan sehat bahkan pada tahun 2019 dan 2020 menunjukkan sangat sehat. Ini dapat diartikan bahwa perbankan semakin efisien dan memiliki produktivitas yang sangat baik dalam mengalokasikan sumber dayanya dan menunjukkan bahwa bank dapat mengelola dengan baik stabilitas keuangannya. Hal tersebut sependapat dengan hasil penelitian yang dilakukan oleh (Fatoni et al., 2019), menurutnya semakin bank tersebut efisien maka akan menurunkan risiko bank tersebut terhadap kebangkrutan.

Berdasarkan analisa di atas, maka BSM ditinjau berdasarkan aspek ketahanan merupakan bank yang sehat sehingga bank dianggap mampu untuk tetap bertahan diwaktu yang akan datang. Sedangkan jika dianalisa berdasarkan aspek stabilitas BSM merupakan bank yang sehat karena memiliki rasio kinerja profitabilitas, likuiditas, dan efisiensi bank serta mampu menjaga kestabilan sistem keuangan. Oleh karena itu, berdasarkan aspek ketahanan dan stabilitas yang diukur dengan indikator modal inti, CAR, NPF, ROA, FDR, dan BOPO menunjukkan bahwa rata-rata tingkat kesehatan BSM dari tahun 2016-2020 dapat dikatakan bahwa BSM bank syariah yang memiliki aset terbesar dengan ketahanan dan stabilitas yang sehat.

\section{Aspek Ketahanan dan Stabilitas BNI Syariah (BNIS)}

Hasil dari pengolahan data sekunder yang diperoleh, maka dapat diketahui aspek ketahanan dan stabilitas dari BNIS pada periode 2016-2020 adalah sebagai berikut: 
Tabel 11. Analisa Rasio Keuangan BNI Syariah (BNIS) Berdasarkan Aspek Ketahanan dan Stabilitas Periode 2016-2020

\begin{tabular}{ccccccc}
\hline Indikator & $\mathbf{2 0 1 6}$ & $\mathbf{2 0 1 7}$ & $\mathbf{2 0 1 8}$ & $\mathbf{2 0 1 9}$ & $\mathbf{2 0 2 0}$ & $\begin{array}{c}\text { Rata-rata } \\
\text { tingkat } \\
\text { kesehatan }\end{array}$ \\
\hline $\begin{array}{c}\text { Modal inti } \\
\text { (Jutaan }\end{array}$ & 2.428 .820 & 3.729 .820 & 4.153 .222 & 4.565 .800 & 5.307 .790 & \\
$\begin{array}{c}\text { Rupiah) } \\
\text { bobot }\end{array}$ & 2 & 2 & 2 & 2 & 3 & 2 \\
Rasio & & & & & & \\
CAR (\%) & 14,92 & 20,14 & 19,31 & 18,88 & 21,36 & \\
bobot & 5 & 5 & 5 & 5 & 5 & 5 \\
NPF (\%) & 2,94 & 2,89 & 2,93 & 3,33 & 3,38 & \\
bobot & 4 & 4 & 4 & 4 & 4 & 4 \\
ROA $(\%)$ & 1,44 & 1,31 & 1,42 & 1,82 & 1,33 & \\
bobot & 4 & 4 & 4 & 5 & 4 & 4 \\
FDR $(\%)$ & 84,57 & 80,21 & 79,62 & 74,31 & 68,79 & \\
bobot & 4 & 4 & 4 & 5 & 5 & 4 \\
BOPO (\%) & 86,88 & 87,62 & 85,37 & 81,26 & 84,06 & \\
bobot & 5 & 5 & 5 & 5 & 5 & 5 \\
\hline & \multicolumn{7}{c}{ TOTAL BOBOT } & & & 4 \\
\hline
\end{tabular}

Su mber: Data yang telah diolah oleh Penulis

Berdasarkan tabel 11 di atas, maka kondisi ketahanan BNIS dianalisa berdasarkan modal inti bank menunjukkan bahwa BNIS dari tahun 2016-2019 termasuk dalam kriteria bank BUKU II dan meningkat pada tahun 2020 menjadi BUKU III, sebab modal inti pada tahun 2020 berada diantara Rp5 triliun s.d Rp30 triliun tidak seperti BSM yang telah mencapai 10 triliun. Merujuk pada peraturan OJK Nomor 12/POJK.03/2020 tentang Konsolidasi Bank Umum, bank wajib memenuhi modal inti minimum paling lambat 31 Desember 2022 sebesar Rp3.000.000.000.000 (tiga triliun rupiah) (Otoritas Jasa Keuangan/OJK, 2020). Berdasarkan ketentuan tersebut, maka modal inti BNIS baru dicapai pada tahun 2017 sedangkan minimal modal inti dari BSM telah dicapai sebelum tahun 2016 (tabel 10). Selain itu, kondisi ketahanan BNIS ditinjau dari rasio CAR memperlihatkan ratarata tingkat kesehatan BNIS pada tahun 2016-2020 menunjukkan sangat sehat dimana rasio CAR tahun 2016-2020 menunjukkan di atas 12\%, artinya BNIS pada periode 2016-2020 memiliki kecukupan modal untuk menunjang kegiatan penyaluran pembiayaan. Lebih lanjut, apabila dianalisa berdasarkan aspek ketahanan yaitu dengan rasio NPF menunjukkan ratarata tingkat kesehatan BNIS pada tahun 2016-2020 menunjukkan sehat, karena nilai NPF BNIS berada pada kisaran 2\% $\leq \mathrm{NPF}>5 \%$ sehingga sesuai kriteria dalam surat edaran Bank Indonesia No. 9/24/DPbs/2007, maka pada kisaran tersebut perbankan dapat dikatakan 
bahwa bank memiliki kualitas pembiayaan yang sehat. Dengan demikian, BNIS dapat menjaga kualitas penyaluran pembiayaan dan permodalannya sehingga kondisi bank di masa yang akan datang dianggap mampu bertahan dalam situasi krisis sekalipun.

Kemudian, jika kondisi kesehatan BNIS dilihat dari aspek stabilitas dengan menggunakan rasio profitabilitas yaitu ROA memperlihatkan bahwa rata-rata tingkat kesehatan BNIS pada tahun 2016-2020 menunjukkan sehat, karena pada tahun 2016-2018 nilai ROA BNIS menunjukkan di atas angka 1\% kemudian pada tahun 2019 naik signifikan di atas 1,5\% meskipun pada tahun berikutnya mengalami penurunan kembali. Maka dapat dikatakan profitabilitas BNIS dilihat dari seberapa besar perusahaan mendapatkan keuntungan terhadap total aset dapat dikatakan sehat karena selama tahun pengamatan memiliki nilai ROA di atas $1 \%$ sehingga BNIS dapat memaksimalkan keuntungannya. Hal tersebut sejalan dengan hasil penelitian (Wilara \& Basuki, 2016), menunjukkan bahwa dalam jangka pendek maupun jangka panjang ROA mengalami kenaikan maka dapat mengindikasi keuntungan yang diperoleh bank syariah, sehingga dapat meningkatkan kemampuan bank syariah dalam meningkatkan modal. Selanjutnya jika kondisi kesehatan BNIS dianalisa dari aspek stabilitas dengan menggunakan rasio likuiditas yaitu FDR memperlihatkan bahwa ratarata tingkat kesehatan BNIS pada tahun secara rata-rata pada periode 2016-2020 menunjukkan sehat sebab selama tahun penelitian nilai FDR di bawah 85\% sehingga dapat dikatakan bahwa BNIS memiliki likuiditas yang memadai untuk menutup kewajibannya kepada nasabah dan stabilitas keuangan perbankan dapat dijaga dengan baik. Namun demikian pada saat terjadinya kesepakatan merger di tahun 2020 FDR BNIS mengalami penurunan yang cukup signifikan dibandingkan tahun sebelumnya yang semula sebesar $74,31 \%$ menjadi $68,79 \%$. Hal ini berbeda dengan BSM yang konsisten mempertahankan FDR di atas 70\% selama periode 2016-2020.

Lebih lanjut, berdasarkan aspek stabilitas BNIS merupakan bank yang sehat karena rasio kinerja profitabilitas, likuiditas, dan efisiensi BNIS mampu menjaga kestabilan sistem keuangannya. Selain itu, apabila ditinjau dari aspek ketahanan dan stabilitas yang diukur dengan Modal inti, CAR, NPF, ROA, FDR, dan BOPO menunjukkan bahwa rata-rata tingkat kesehatan BNIS dari tahun 2016-2020 dapat dikatakan sebagai bank yang sehat.

\section{Aspek Ketahanan dan Stabilitas BRI Syariah (BRI)}

Hasil dari pengolahan data sekunder yang diperoleh, maka dapat diketahui aspek ketahanan dan stabilitas dari BRIS pada periode 2016-2020 adalah sebagai berikut: 
Tabel 12. Analisa Rasio Keuangan BRI Syariah (BRIS) Berdasarkan Aspek Ketahanan dan Stabilitas Periode 2016-2020

\begin{tabular}{ccccccc}
\hline Indikator & $\mathbf{2 0 1 6}$ & $\mathbf{2 0 1 7}$ & $\mathbf{2 0 1 8}$ & $\mathbf{2 0 1 9}$ & $\mathbf{2 0 2 0}$ & $\begin{array}{c}\text { Rata-rata } \\
\text { tingkat } \\
\text { kesehatan }\end{array}$ \\
\hline $\begin{array}{c}\text { Modal inti } \\
\text { (Jutaan Rupiah) }\end{array}$ & 2.336 .293 & 2.452 .308 & 4.743 .689 & 4.770 .101 & 5.081 .223 & \\
bobot & 2 & 2 & 2 & 2 & 3 & 2 \\
Rasio & & & & & & \\
CAR (\%) & 20,30 & 20,29 & 29,79 & 25,26 & 19,04 & \\
bobot & 5 & 5 & 5 & 5 & 5 & 5 \\
NPF $(\%)$ & 4,57 & 6,43 & 6,73 & 5,22 & 3,24 & \\
bobot & 4 & 3 & 3 & 3 & 4 & 3 \\
ROA (\%) & 0,95 & 0,51 & 0,43 & 0,31 & 0,81 & \\
bobot & 3 & 3 & 2 & 2 & 3 & 3 \\
FDR $(\%)$ & 81,47 & 71,87 & 75,49 & 80,12 & 80,99 & \\
bobot & 4 & 5 & 4 & 4 & 4 & 4 \\
BOPO $(\%)$ & 91,33 & 95,24 & 95,32 & 96,8 & 91,01 & \\
bobot & 5 & 3 & 3 & 2 & 5 & 4 \\
& \multicolumn{7}{c}{ TOTAL BOBOT } & & & $\mathbf{3 , 5}$ \\
\hline
\end{tabular}

Su mber: Data yang telah diolah oleh Penulis

Berdasarkan tabel 12, kondisi ketahanan BRIS yang ditinjau dari modal inti bank menunjukkan bahwa BRIS dari tahun 2016-2019 termasuk dalam kriteria bank BUKU II dan naik pada tahun 2020 menjadi BUKU III, sebab modal inti pada tahun 2020 berada diantara Rp 5 triliun s.d Rp30 triliun. Modal inti ini digunakan untuk penyangga serta menghindari bank dari risiko kegagalan. Oleh karenanya BRIS memiliki permodalan yang kuat dan terus meningkat dari tahun ke tahun. Jika dilihat dari peraturan OJK Nomor 12/POJK.03/2020 tentang Konsolidasi Bank Umum, bank wajib memenuhi modal inti minimum paling lambat 31 Desember 2022 sebesar Rp3.000.000.000.000 (tiga triliun rupiah) (Otoritas Jasa Keuangan/OJK, 2020), maka minimum modal inti tersebut baru dicapai pada tahu 2018 (tabel 12). Kemudian kondisi ketahanan BRIS dianalisa dari rasio CAR menunjukkan ratarata tingkat kesehatan BRIS pada tahun 2016-2020 menunjukkan sangat sehat. Selain itu dengan nilai rasio CAR di atas 12\%, artinya BRIS selama tahun 2016-2020 memiliki kecukupan modal untuk melakukan ekspansi penyaluran pembiayaan dengan modal yang memadai. Hal tersebut sejalan dengan penelitian (Marlyna \& Wirando, 2018), menunjukkan bahwa jika bank syariah memiliki CAR yang sehat maka dapat dikatakan bank syariah tersebut terhindar dari risiko kerugian dan dianggap dapat mengantisipasi kemungkinan adanya risiko-risiko kerugian tersebut. Sedangkan, aspek ketahanan berdasarkan rasio NPF menunjukkan rata-rata tingkat kesehatan BRIS pada tahun 2016-2020 menunjukkan cukup 
sehat, karena nilai NPF BRIS tiga tahun berturut-turut yaitu 2017-2019 berada pada kisaran $5 \% \leq \mathrm{NPF}>8 \%$ sehingga sesuai kriteria dalam surat edaran Bank Indonesia No. 9/24/DPbs/2007. Namun demikian, apabila dianalisa lebih lanjut kualitas pembiayaan bermasalah BRIS memiliki relatif cukup tinggi pada periode 2017-2019 sehingga risiko gagal bayar atas penyaluran pembiayaan di BRIS lebih tinggi dibandingkan dengan BSM dan BNIS. Hal tersebut mengakibatkan penurunan CAR di tahun 2020 menjadi 19,04\% dibandingkan dengan CAR pada tahun 2019 sebesar 25,26\%. Penurunan CAR tahun 2020 tersebut dapat bersumber dari rendahnya laba yang ditahan dari tahun sebelumnya dikarenakan besarnya biaya penghapusan buku yang dilakukan oleh BRIS ditahun 2019 dalam rangka menjaga NPF di bawah 5\%. Namun demikian, rata-rata kualitas pembiayaan BRIS relatif tinggi, yaitu di atas 5\% sehingga diperlukan pengawasan dan tindak lanjut dari pihak bank hasil merger, dalam hal ini Bank Syariah Indonesia (BSI).

Jika kondisi kesehatan BRIS ditinjau dari aspek stabilitas dengan menggunakan rasio profitabilitas yaitu ROA menunjukkan bahwa rata-rata tingkat kesehatan BRIS pada tahun 2016-2020 menunjukkan kurang sehat, karena pada tahun 2016-2018 nilai ROA BRIS menunjukkan di bawah angka 1\% bahkan dua tahun berturut-turut yaitu tahun 2018 dan 2019 BRIS memiliki nilai ROA di bawah 0,5\%. Maka dapat dikatakan profitabilitas BRIS ditinjau dari seberapa besar perusahaan mendapatkan keuntungan terhadap total aset dapat dikatakan kurang sehat karena selama tahun pengamatan memiliki nilai ROA di bawah $1 \%$ bahkan di bawah 0,5\%, maka BRIS dapat dikatakan kurang maksimal dalam memperoleh keuntungan dan meningkatkan modal bank. Selanjutnya, ditinjau dari aspek stabilitas dengan menggunakan rasio likuiditas yaitu FDR menunjukkan bahwa rata-rata tingkat kesehatan BRIS pada tahun 2016-2020 sehat bahkan tahun 2017 dinyatakan sangat sehat, sebab selama tahun penelitian nilai FDR di bawah $85 \%$ sehingga dapat dikatakan bahwa BRIS memiliki likuiditas yang memadai untuk menutup kewajibannya kepada nasabah dan stabilitas keuangan perbankan dapat dijaga dengan baik. Sedangkan aspek stabilitas jika dianalisa dari rasio efisiensi yaitu BOPO menunjukkan bahwa rata-rata tingkat kesehatan BRIS menunjukkan cukup sehat, sebab tahun 2017 dan 2018 BRIS cukup mampu untuk melakukan efisiensi dalam pengeluaran biaya operasional, bahkan tahun 2016 dan 2020 bank dinyatakan dalam keadaan sehat dalam melakukan efisiensi meskipun tahun 2019 dapat dinyatakan kurang efisien karena nilai BOPO di atas $96 \%$.

Selanjutnya, merujuk analisa di atas, maka apabila ditinjau dari aspek stabilitas BRIS merupakan bank yang kurang sehat jika dilihat dari rasio profitabilitas, cukup sehat jika dilihat dari rasio efisiensi, dan dinyatakan sehat apabila dilihat dari rasio likuiditas. Oleh 
sebab itu, maka BRIS cukup mampu dalam menjaga kestabilan sistem keuangan. Sehingga, apabila dianalisa dari aspek ketahanan dan stabilitas yang diukur dengan Modal inti, CAR, NPF, ROA, FDR, dan BOPO menunjukkan bahwa rata-rata tingkat kesehatan BRIS dari tahun 2016-2020 dapat dikatakan bank yang cukup sehat.

\section{Analisa Komparasi Aspek Ketahanan dan Stabilitas antara BSM, BNIS dan BRIS}

Hasil perbandingan aspek ketahanan dan stabilitas masing-masing bank syariah yang melakukan merger (BSM, BNIS dan BRIS) terdapat pada tabel 13 sebagai berikut:

\section{Tabel 13. Analisa Komparasi Rasio Keuangan BSM, BNIS, BRIS Berdasarkan Aspek Ketahanan dan Stabilitas Periode 2016-2020}

\begin{tabular}{|c|c|c|c|c|c|c|c|c|c|c|c|c|c|}
\hline \multirow[b]{3}{*}{ Bank } & \multicolumn{6}{|c|}{ Posisi 2020} & \multicolumn{6}{|c|}{ Rata-Rata Periode 2016-2020 } & \multirow{3}{*}{$\begin{array}{c}\text { Rata-Rata } \\
\text { Tingkat } \\
\text { Kesehatan }\end{array}$} \\
\hline & \multicolumn{3}{|c|}{ Ketahanan } & \multicolumn{3}{|c|}{ Stabilitas } & \multicolumn{3}{|c|}{ Ketahanan } & \multicolumn{3}{|c|}{ Stabilitas } & \\
\hline & $\begin{array}{c}\text { Modal } \\
\text { Inti } \\
\text { (Jutaan } \\
\text { Rupiah) }\end{array}$ & $\begin{array}{c}\text { CAR } \\
(\%)\end{array}$ & $\begin{array}{l}\text { NPF } \\
(\%)\end{array}$ & $\begin{array}{c}\text { ROA } \\
(\%)\end{array}$ & $\begin{array}{c}\text { FDR } \\
(\%)\end{array}$ & $\begin{array}{c}\text { BOPO } \\
(\%)\end{array}$ & $\begin{array}{c}\text { Modal } \\
\text { Inti } \\
\text { (Jutaan } \\
\text { Rupiah) }\end{array}$ & $\begin{array}{c}\text { CAR } \\
(\%)\end{array}$ & $\begin{array}{l}\text { NPF } \\
(\%)\end{array}$ & $\begin{array}{c}\text { ROA } \\
(\%)\end{array}$ & $\begin{array}{l}\text { FDR } \\
(\%)\end{array}$ & $\begin{array}{c}\text { BOPO } \\
(\%)\end{array}$ & \\
\hline BSM & $10,052,432$ & 16.88 & 2.51 & 1.65 & 73.98 & 81.81 & $7,891,873$ & 15.84 & 3.54 & 1.08 & 75.33 & 88.79 & 4.2 \\
\hline BNIS & $5,307,790$ & 21.36 & 3.38 & 1.33 & 68.79 & 84.06 & $4,037,090$ & 18.92 & 3.09 & 1.46 & 77.50 & 85.04 & 4 \\
\hline BRIS & $5,081,223$ & 19.04 & 3.24 & 0.81 & 80.99 & 91.01 & $3,876,723$ & 22.94 & 5.24 & 0.60 & 77.99 & 93.94 & 3.5 \\
\hline
\end{tabular}

Berdasarkan tabel 13 di atas, maka berdasarkan bobot hasil terhadap analisa rasio keuangan antara BSM, BNIS dan BRIS, maka BSM menduduki peringkat pertama berdasarkan aspek ketahanan dan stabilitas dari bank syariah yang melakukan merger.

Selanjutnya berdasarkan aspek ketahanan untuk aspek modal inti, BSM memiliki modal inti paling besar yaitu mencapai Rp10,052 triliun pada tahun 2020 dengan rata-rata Rp7,891 triliun sehingga BSM merupakan bank BUKU III. Pada sisi lain, BNIS dan BRIS meskipun pada tahun 2020 telah memenuhi kiriteria sebagai bank BUKU III, namun secara rata-rata BNIS dan BRIS modal intinya masih di bawah Rp5 triliun. Menurut Peraturan Otoritas Keuangan Nomor 12/POJK.03/2020 tentang Konsolidasi Bank Umum, BSM, BNIS, dan BRIS telah memenuhi modal inti minimum menurut peraturan OJK yaitu sebesar Rp. 3.000.000.000,- (tiga triliun rupiah) sehingga dapat dikatakan BSM, BNIS, dan BRIS telah memenuhi syarat sebagai bank umum dan dapat melakukan penggabungan, peleburan, atau integrasi atau dengan kata lain akuisisi dan merger. Namun demikian harus diperhatikan prinsip keadilan, terkait dengan kontribusi modal inti BSM yang mencapai dua kali lipat dibandingkan BNIS dan BRIS. Menurut Fadlih Rifenta (2018), prinsip keadilan dalam perpektif syariah atau dalam bahasa arab disebut dengan $A l-A d l$, yaitu sikap dan perilaku dalam rangka menegakkan kebenaran dan tidak terjadi perselisihan maupun salam paham 
sesama umat manusia. Selain itu adil juga dapat diartikan dengan memberikan sesuatu kepada pihak yang berhak atas sesuatu tersebut. Bahkan, adil juga dapat diartikan menempatkan sesuatu sesuai dengan kemampuan, pengalaman, kontribusi, porsinya tanpa adanya sikap untuk mengurangi dan melebihi. Oleh karenanya berdasarkan jumlah modal inti, maka BSM memiliki kontribusi terbesar terhadap berdirinya BSI. Pada sisi pengalaman, BSM juga merupakan bank syariah kedua setelah Bank Muamalat Indonesia sehingga sumber daya insani, prasarana dan sarana yang dimiliki BSM lebih baik dibandingkan dengan BNIS dan BRIS

Rasio lainnya terkait dengan aspek ketahanan adalah rasio CAR, diketahui bahwa seluruh bank syariah yang melakukan merger yaitu BSM, BNIS dan BRIS telah memenuhi modal inti yang dipersyaratkan oleh regulator yaitu minimal Rp3 triliun, maka CAR dari seluruh bank tersebut juga telah melebihi 12\%. Oleh karena itu, bank hasil merger, yaitu Bank Syariah Indonesia (BSI) telah memiliki kecukupan modal yang memadai untuk melakukan ekspansi bisnisnya dan juga tersedianya dana yang memadai untuk digunakan sebagai cadangan untuk menutupi atau mengcover apabila terjadi kerugian yang dialami bank tersebut.

Sedangkan pada aspek ketahanan berdasarkan rasio NPF, bank syariah merger pada tahun 2020 yang memiliki kualitas yang paling baik adalah BSM yaitu sebesar 2,51\% dengan rata-rata NPF 3,54\%. Sedangkan BRIS secara rata-rata memiliki NPF di atas 5\% atau 5,24\% sehingga kualitas penyaluran pembiayaan selama lima tahun terakhir dari BRIS perlu diperbaiki ke depannya. Sehingga bank hasil merger yaitu BSI harus melakukan penilaian terhadap pembiayaan bermasalah portofolio pembiayaan BRIS, agar tidak semakin besar opportunity cost yang harus ditanggung BSI sehingga dapat memitigasi serta mengurangi jumlah kerugian yang akan timbul pada kemudian hari (Nugroho et al., 2017). Sedangkan NPF pada tahun 2020 BNIS juga memiliki NPF yang tinggi, yaitu mencapai 3,38\% sehingga ke depannya portofolio pembiayaan yang dimiliki oleh BNIS juga perlu mendapat perhatian khusus agar kualitas pembiayaan bank tersebut tidak bertambah buruk sehingga pendapatan dari pembiayaan bank merger BSI dapat terjaga dengan baik.

Lebih lanjut, analisa aspek stabilitas berdasarkan rasio profitabilitas atau ROA, maka BSM memiliki rasio yang paling baik dimana pada tahun 2020, BSM memiliki ROA sebesar 1,65\%. Sedangkan ROA dari BRIS tidak terlalu baik pada tahun 2020 yaitu sebesar $0,81 \%$ dengan rata-rata sebesar 0,60\% selama periode 2016-2020. Oleh karenanya penyaluran pembiayaan dari BRIS meskipun memiliki FDR yang besar tetapi dikarenakan kualitasnya kurang baik yang ditunjukkan dengan NPF yang tinggi sehingga tidak dapat berkontribusi 
signifikan terhadap laba yang direpresentasikan dengan ROA. Sedangkan ROA BNIS pada tahun 2020 sebesar $1,33 \%$ juga relatif lebih rendah dari rata-rata lima tahun terakhir (20162020) sebesar $1,46 \%$. Oleh karena itu, BSM sebagai kontributor terbesar dalam modal inti dan juga laba yang besar terhadap BSI sudah selayaknya, pembagian struktur manajemen perusahaan tidak dibagi secara merata, tetapi sebaiknya pembagian struktur manajemen BSI harus didasarkan atas azas keadilan baik dari kontribusi modal, laba, kompetensi, pengalaman dan juga sarana serta prasarana yang telah dimiliki.

Perbandingan stabilitas keuangan antara ketiga bank syariah yang melakukan merger, maka berdasarkan tabel 13 di atas, maka dapat diketahui bahwa FDR BNIS pada tahun 2020 mengalami penurunan yang paling signifikan dibandingkan tahun sebelumnya. Sedangkan BSM dan BRIS masih mampu menjaga konsistensi penyaluran pembiayaannya meskipun terjadi pandemi Covid-19. Pada rasio efisiensi atau BOPO, pada tahun 2020 BSM memiliki produktivitas atau pengalokasian itusumber daya yang paling baik dengan BOPO paling rendah yaitu sebesar $81,81 \%$ lebih rendah daripada rata-rata BOPO lima tahun terakhir. Sedangkan BOPO dari BNIS pada tahun 2020 memiliki rasio yang lebih tinggi dari rata-rata BOPO dalam lima tahun terakhir. Rasio BOPO BNIS pada tahun 2020 sebesar 84,06\% sedangkan rata-rata lima tahun terakhir sebesar 85,04\%. Sedangkan BRIS pada tahun 2020 sebesar 91,01\% mengalami penurunan dari lima tahun terakhir dengan rata-rata 93,94\%. Semakin bank tersebut efisien atau rasio BOPO nya semakin tinggi, maka akan menurunkan risiko bank tersebut terhadap kebangkrutan (Fatoni et al., 2019).

Dengan demikian, secara keseluruhan analisa rasio keuangan berdasarkan aspek ketahanan dan aspek stabilitas, maka BSM menduduki peringkat pertama dengan rata-rata tingkat kesehatan 4,2. Pada peringkat kedua diduduki oleh BNIS dengan rata-rata tingkat kesehatan 4 dan terakhir BRIS dengan rata-rata tingkat kesehatan 3,5. Oleh karenanya berdasarkan hasil dari olah penelitian ini, maka diharapkan penanganan bank hasil merger (BSI) dapat menyesuaikan dengan tata kelola dari BSM dikarenakan BSM memiliki rata-rata tingkat kesehatan yang paling baik.

Proses merger dari ketiga bank syariah yang meliputi BSM, BNIS, dan BRIS menjadi Bank Syariah Indonesia terjadi begitu cepatnya. Dimana diawali pada tanggal 12 Oktober 2020 terjadi Conditional Merger Agreement (CMA) yaitu kesepahaman untuk melakukan merger yang diinisiasi oleh pemerintah melalui Kementerian BUMN (Rini \& Wiratmini, 2020). Selanjutnya pada tanggal 1 Februari 2021, izin penggabungan usaha tiga bank syariah tersebut dikeluarkan oleh Otoritas Jasa Keuangan (OJK) dengan Nomor: SR-3/PB.1/2021 perihal Pemberian Izin Penggabungan PT. Bank Syariah Mandiri dan PT Bank BNI Syariah 
ke dalam PT Bank BRI Syariah, serta Izin Perubahan Nama dengan Menggunakan Izin Usaha PT Bank BRIsyariah Tbk Menjadi Izin Usaha atas nama PT Bank Syariah Indonesia Tbk sebagai Bank Hasil Penggabungan (Sitorus, 2021). Dengan demikian, proses merger hanya memakan waktu tiga bulan yang berdampak perubahan dimana operasional ketiga bank tersebut menjadi satu sehingga terdapat potensi kajian tidak dilakukan secara komprehensif oleh pihak-pihak yang netral atau objektif sehingga kemungkinan terdapat pihak yang dirugikan dalam proses ini. Oleh karenanya, kelanjutan dari proses merger Bank Syariah Indonesua ini tentunya masih terus berlangsung dan niat baik pemerintah harus didukung untuk menjadikan Indonesia sebagai pusat keuangan dan ekonomi syariah yang akan berdampak terhadap kesejahteraan masyrakat.

\section{KESIMPULAN DAN SARAN}

Aspek ketahanan dan stabilitas BSM, BNIS, dan BRIS yang dianalisa berdasarkan rasio keuangan Modal inti, CAR, NPF, ROA, FDR, dan BOPO secara umum kinerja ketiga bank tersebut selama tahun 2016-2020 adalah sehat. Namun demikian apabila dianalisa lebih lanjut, BSM merupakan bank yang paling sehat diantara dua bank lainnya, sedangkan BNIS memiliki stabilitas dan ketahanan bank yang sehat peringkat kedua setelah BSM. Selanjutnya BRIS menduduki tempat terakhir dari segi aspek stabilitas dan ketahanan dalam bank syariah merger karena BRIS memiliki stabilitas dan ketahanan bank dengan rata-rata tingkat kesehatan cukup sehat. Maka, jika dilakukan merger atau penggabungan pada BSM, BNIS, dan BRIS menjadi Bank Syariah Indonesia (BSI) apabila ditinjau dari aspek ketahanan dan stabilitas dapat disimpulkan bahwa BSI kedepannya akan mampu bertahan dan sistem keuangan dapat tetap stabil sehingga dapat memperkuat kinerja operasional untuk ke depannya, karena dua dari tiga bank hasil penggabungan memiliki aspek ketahanan dan stabilitas yang sehat. Namun demikian agar kinerja yang dihasilkan dapat optimal, maka seyogyanya yang memiliki kinerja dan pengalaman yang lebih lama yaitu BSM dapat menjadi pengelola utama dari bank merger tersebut yang didasarkan azas keadilan.

Implikasi manajerial dari penelitian ini didapatkan bahwa ketahanan dan stabilitas bank syariah dari BSM, BNIS, dan BRIS dapat mempengaruhi pencapaian kinerja keuangan jika dilakukan penggabungan atau merger. Bank syariah diharapkan lebih memperhatikan kinerja keuangannya, terutama BRIS yang mempunyai nilai rata-rata tingkat kesehatan sebesar 3,5 jauh dibawah BSM dan BNIS agar lebih optimal dalam melakukan kinerja operasional, sehingga Bank Syariah Indonesia (BSI) hasil penggabungan BSM, BNIS, dan 
BRIS ke depannya akan mampu bekerja secara optimal dan dapat memperkuat kinerja operasionalnya, sehingga dapat mencapai visi dan misi merger bank syariah tersebut.

\section{REFERENSI}

Afoukane, M., Utami, W., \& Nugroho, L. (2021). Assessing The Adaptability of Islamic Microfinance Loans to The Needs of Small Enterprises in Indonesia. Journal of Islamic Economics \& Social Science (JIESS), 2(1), 9-23.

Arafah, W., \& Nugroho, L. (2016). Maqhashid Sharia in Clean Water Financing Business Model at Islamic Bank. International Journal of Business and Management Invention, $5(2), 22-32$.

Aziz, L. H., Malle, S., Ilham, A., Fatriansyah, A., Raya, F., Nugroho, L., Wahyudi, A. B. (2021). Akuntansi Syariah (Sebuah Tinjauan Teori dan Praktis) (First). Bandung: Penerbit Widina Bhakti Persada Bandung. Retrieved from www.penerbitwidina.com

Bank Indonesia. (2007). Surat Edaran Bank Indonesia No: 9/24 / DPbs / 2007 tentang Sistem Penilaian Tingkat Kesehatan Bank Umum Berdasarkan Prinsip Syariah.

Boia, M. (2015). Growing a Business - Mergers and Acquisitions. Bulletin of Taras Shevchenko National University of Kyiv Economics, 9(174), 31-37. https://doi.org/10.17721/1728-2667.2015/174-9/5

Esterlina, P. \& N. N. F. (2017). Analisis Kinerja Keuangan Perusahaan Sebelum dan Sesudah Merger dan Akuisisi. Jurnal Administrasi Bisnis (JAB), 47(1). https://doi.org/10.31479/m.v9i1.19

Fadlih Rifenta. (2018). Konsep Adil dalam Hukum Waris Islam. FUADUNA: Jurnal Kajian Kegamaan Dan Kemasyarakatan, 02(01), 23-37.

Fatoni, A., Sidiq, S., Ekonomi, J., Universitas, S., Ageng, S., Ilmu, J., Indonesia, I. (2019). Analisis Perbandingan Stabilitas Sistem Perbankan Syariah dan Konvensional di Indonesia 1. Jurnal Ekonomi, Keuangan, Perbankan dan Akuntansi, 11(2), 179-198. https://doi.org/10.35313/ekspansi.v11i2.1350

Hidayah, N., Nugroho, L., Prihanto, H., \& Prihantini, D. (2021). Company Characteristics, Disclosure of Social Responsibility, and Its Impact on Company Performance: an Empirical Study in Indonesia. Journal of Asian Finance, Economics and Business, 8(6), 889-895. https://doi.org/10.13106/jafeb.2021.vol8.no6.0889

Hidayat, A. A. N., \& Antara. (2020). OJK Berharap Pasar Perbankan Syariah Naik Menjadi 10 Persen Akibat Merger - Bisnis Tempo.co. Retrieved August 1, 2021, from https://bisnis.tempo.co/read/1412129/ojk-berharap-pasar-perbankan-syariah-naikmenjadi-10-persen-akibat-merger

Hien, N. T. T., \& Tuan, P. D. (2014). Factors Affecting The Loan Loss Provision in Vietnamese System of Commercial Banks. Journal of Economics Development, JED 222, 89-106. https://doi.org/10.24311/jed/2014.222.06

Ihwanudin, N., Maulida, S., Ilham Akbar Fatriansyah, A., Sari Rahayu, S., Nugroho, L., Widyastuti, S., Arzhi Jiwantara, F. (2020). Pengantar Perbankan Syariah (Konsep, Regulasi \& Praktis). Widina Bhakti Persada Bandung. Retrieved from www.penerbitwidina.com

Marlyna, D., \& Wirando, M. A. (2018). Analisa Tingkat Kesehatan Bank Syariah. TECHNOBIZ: International Journal of Business, 1(1), 19-24. https://doi.org/10.33365/tb.v1i1.202

Matoenji, E. Y., Nugroho, L., \& Soeharjoto. (2021). Determinasi Pertumbuhan Laba Bank Syariah Berdasarkan Aspek Pembiayaan UMKM, Jumlah Outlet dan Kualitas 
Pembiayaan. Sistem Informasi, Keuangan, Auditing Dan Perpajakan (SIKAP), 6(1), 125-140.

Mersland, R., \& Strøm, R. Ø. (2008). Performance and Trade-Offs in Microfinance Organisations-Does Ownership Matter? Journal of International Development, 20(5), 598-612. https://doi.org/10.1002/jid

Miftakhul Jannah, D., \& Nugroho, L. (2019). Strategi Meningkatkan Eksistensi Asuransi Syariah di Indonesia. Jurnal Maneksi, 8(1), 169-176.

Muin, S. A. (2017). Analisis Faktor-Faktor yang Memengaruhi Rentabilitas pada P.T. Bank Rakyat Indonesia (Persero) Tbk. Periode 2011-2016. Jurnal Economix, 5(137), 137-147.

Muniarty, P., Surya Abbas, D., Fatira, M. A., Sugiri, D., Nurfadilah, D., Moridu, I., Rismawati, N. (2020). Manajemen Perbankan. Retrieved from www.penerbitwidina.com

Nugroho, L. (2020). Strategi Sumber Dana, Pembiayaan dan Jasa Bank Syariah. In U. Saripudin (Ed.), Pengantar Perbankan Syariah (pp. 177-192). Widina Bhakti Persada Bandung. https://doi.org/10.1017/CBO9781107415324.004

Nugroho, L., \& Anisa, N. (2018). Pengaruh Manajemen Bank Induk, Kualitas Aset, dan Efisiensi terhadap Stabilitas Bank Syariah di Indonesia (Periode Tahun 2013-2017). Inovbiz: Jurnal Inovasi Bisnis, 6(2), 114-122.

Nugroho, L., Aryani, E., \& Mastur, Akhmad Amien. (2019). Analisa Pengaruh Perputaran Kas dan Perputaran Piutang terhadap Return on Asset (ROA) pada Perusahaan LQ 45 yang Terdaftar di BEI Tahun 2012-2017 . Inovbiz: Jurnal Inovasi Bisnis, 7, 20-25.

Nugroho, L., \& Bararah, H. N. (2018). Pengaruh Good Corporate Governance dan Biaya Operasional dan Pendapatan Operasional (BOPO) terhadap Stabilitas Keuangan Bank Umum Syariah di Indonesia Tahun 2012-2017. Inovbiz: Jurnal Inovasi Bisnis, 6(2), 160-169.

Nugroho, L., Hidayah, N., Badawi, A., \& Mastur, A. A. (2020). The urgency of Leadership in Islamic Banking Industries Performance. In The 1st Annual Conference Economics, Business, and Social Sciences (pp. 1-7). https://doi.org/10.4108/eai.26-3-2019.2290681

Nugroho, L., \& Husnadi, T. C. (2014). State-Owned Islamic Bank (BUMN) in Realizing The Benefit of Ummah (Maslahah) and Indonesia as Islamic Financial Center in The World. In 11th International Research Conference on Quality, Innovation and Knowledge Management. Bandung (p. 20).

Nugroho, L., \& Malik, A. (2020). Determinasi Kualitas Kredit Kepemilikan Rumah (KPR) Berdasarkan Perspektif Sumber Angsuran dan Rasio Fraud Account Officer. Moneter, 7(1), 71-79.

Nugroho, L., Mastur, A. A., Harnovinsah, \& Aryanti, W. (2020). The Contribution of Islamic Bank in Poverty Alleviation. Al-Ahkam Jurnal Pemikiran Hukum Islam, 30(1), 19-38.

Nugroho, L., Utami, W., Doktorlina, C. M., \& Husnadi, T. C. (2017). Islamic Banking Capital Challenges To Increase Business Expansion (Indonesia Cases). International Journal of Commerce and Finance, 3(2), 1-10.

Nugroho, L., Utami, W., Sukmadilaga, C., \& Fitrijanti, T. (2017). The Urgency of Allignment Islamic Bank to Increasing the Outreach (Indonesia Evidence). International Journal of Economics and Financial Issues, 7(4), 283-291.

Nugroho, L., Villaroel, W., \& Utami, W. (2017). The Challenges of Bad Debt Monitoring Practices in Islamic Micro Banking. European Journal of Islamic Finance, 11, 1-11.

Nugroho, L., Villaroel, W., \& Utami, W. (2018). The Challenges of Bad Debt Monitoring Practices in Islamic Micro Banking. European Journal of Islamic Finance, 11, 1-11. Retrieved from http://www.ojs.unito.it/index.php/EJIF

OJK. (2020). Statistik Perbankan Indonesia. Retrieved August 1, 2021, from https://www.ojk.go.id/id/kanal/perbankan/data-dan-statistik/statistik-perbankanindonesia/default.aspx 
Otoritas Jasa Keuangan/OJK. (2016). Nomor 6/POJK.03/2016 tentang Kegiatan Usaha dan Jaringan Kantor. Jakarta.

Otoritas Jasa Keuangan/OJK. (2017). POJK Nomor 15/POJK.03/2017 tentang Penetapan Status dan Tindak Lanjut Pengawasan Bank Umum.

Otoritas Jasa Keuangan/OJK. (2020). Peraturan Otoritas Jasa Keuangan Nomor 12/POJK.03/2020 tentang Konsolidasi Bank Umum.

Pinasti, W. F., \& Mustikawati, R. I. (2018). Pengaruh CAR, BOPO, NPL, NIM Dan LDR terhadap Profitabilitas Bank Umum Periode 2011-2015. Nominal, Barometer Riset Akuntansi Dan Manajemen, 7(1), 126-142. https://doi.org/10.21831/nominal.v7i1.19365

Rini, A. S., \& Wiratmini, N. P. E. (2020). Pengumuman Resmi Merger Bank Syariah BUMN Ditunda jadi Besok - Finansial Bisnis.com. Retrieved November 14, 2021, from https://finansial.bisnis.com/read/20201012/231/1304124/pengumuman-resmi-mergerbank-syariah-bumn-ditunda-jadi-besok

Sabariah, Y., \& Nik Ab Halim, N. A. (2020). Towards Maqasid Shariah In Sustaining The Environment Through Impactful Strategies. International Journal of Islamic Business, 5(1), 36-45.

Setiawan, A. (2017). Analisis Pengaruh Tingkat Kesehatan Bank terhadap Return on Asset. Jurnal Analisa Akuntansi Dan Perpajakan, 1(2), 138-151. https://doi.org/10.25139/jaap.v1i2.346

Setiawan, I. (2020). Analisis Peran Perbankan terhadap Pertumbuhan Ekonomi di Indonesia: Bank Syariah Versus Bank Konvensional. Jurnal Akuntansi, Ekonomi dan Manajemen Bisnis, 8(1), 52-60. https://doi.org/10.30871/jaemb.v8i1.1649

Sholikhah, M. D. A. (2019). Pengaruh Cadangan Kerugian Penurunan Nilai (CKPN) dan Pertumbuhan Volume Pembiayaan Serta Inflasi terhadap Non Performing Financing pada Bank Umum Syariah di Indonesia Periode 2012-2016. Jurnal Ilmu Akuntansi Mulawarman (JIAM), 3(4).

Sitorus, R. (2021). Resmi! Merger Bank Syariah BUMN Kantongi Izin dari OJK - Finansial Bisnis.com. Retrieved November 14, 2021, from https://finansial.bisnis.com/read/20210127/90/1348702/resmi-merger-bank-syariahbumn-kantongi-izin-dari-ojk

Soekapdjo, S., Tribudhi, D. A., \& Nugroho, L. (2019). Pengaruh Fundamental Ekonomi dan Kinerja Keuangan terhadap Kredit Bermasalah pada Bank Syariah di Indonesia. Ekonika: Jurnal Ekonomi Universitas Kadiri, 4(2), 126. https://doi.org/10.30737/ekonika.v4i2.327

Sukmadilaga, C., \& Nugroho, L. (2017). Pengantar Akuntansi Perbankan Syariah "Prinsip, Praktik dan Kinerja. ” Pusaka Media, Bandar Lampung, Indonesia.

Syakhrun, M., Anwar, A., \& Amin, A. (2019). Pengaruh CAR, BOPO, NPF dan FDR terhadap Profitabilitas pada Bank Umum Syariah di Indonesia. Bongaya Journal for Research in Management (BJRM), 2(1), 1-10. https://doi.org/10.37888/bjrm.v2i1.102

TheAsianBanker. (2021). Largest Banks. Retrieved August 1, 2021, from https://www.theasianbanker.com/ab500/2018-2019/largest-islamic-banks

Vania, A. S., Nugraha, E., \& Nugroho, L. (2018). Does Earning Management Happen in Islamic Bank? (Indonesia and Malaysia Comparison). International Journal of Commerce and Finance, 4(2), 47-59. Retrieved from https://databoks.katadata.co.id

Wella, L. S., \& Asriyanto, D. P. (2020). Merger Bank Syariah Himbara Bakal Dongkrak Pangsa Pasar - Kabar Tegal. Retrieved August 1, 2021, from https://kabartegal.pikiranrakyat.com/nasional/pr-931067633/merger-bank-syariah-himbara-bakal-dongkrakpangsa-pasar

Widyatini, I. R. (2017). The Effect of Risk Taking Behavior Performed by The Economic Agents Toward The Risk of the Bankruptcy of Banks. Review of Integrative Business 
and Economics Research, 6(2), 234-243.

Wilara, G. R., \& Basuki, A. T. (2016). Determinan Ketahanan Modal Bank Syariah di Indonesia: Pendekatan ECM. Jurnal Ekonomi \& Studi Pembangunan, 17(2), 157-167. https://doi.org/10.18196/jesp.17.2.3957

Yanti, N. (2020). Peran Perbankan Syariah terhadap Kesejahteraan di Indonesia. Jurnal Riset Akuntansi dan Bisnis, 20(1), 82-91. https://doi.org/10.30596/jrab.v20i1.4956 